\title{
ECOLOGICAL READING ON SELECTED AYURZANA AND YONG SHU HOONG's POEMS
}

\author{
Kristiawan Indriyanto \\ Doctoral Program, UniversitasGadjahMada \\ kristiawanindriyanto@gmail.com \\ Yogyakarta, Indonesia
}

\begin{abstract}
This paper explores how nature is depicted by two poets of different nationality using ecocriticism. Ecological approach is used as framework to focus more on the connection and relationship between human and their environment and the possible impact on the disruption of human-nature relationship. People living in different environment will have different reception toward their surroundings. The aim of this paper is to explore how both poets describe nature in their selected works. Ayurzana and Yong ShuHoong represent two poets exposed to different environment;hence, this paper seeks to present how different Ayurzana who lives in a rural area portray his surrounding compared with Hoong as an urban dweller. As a native Mongolian, Ayurzana explores the close connection between Mongolian people and nature. On the other hand, Hoong's poetry elaborates life in cities and people that become detached from the natural environment. By analyzing two poets from different living conditions, this paper acknowledges that ecological issue might differ from one region to another.
\end{abstract}

\section{Key words: Ecocriticism, eco poetry, space and place}

\section{INTRODUCTION}

One of the trends in literature nowadays is the increasing awareness toward environmental issue with the advent of ecocriticism. Ecocriticism focuses on the relationship between literature and the physical environment, or in other word earth centered approach-. ${ }^{1}$ Different from other criticisms that place human in the center, ecocriticism revolves around nature instead.Sumathy notes that Ecocriticism takes as its subject the interconnections between nature and culture. ${ }^{2}$ While acknowledging the fact that ecocriticism enables literature to be viewed in new and greener light, Bryson criticizes the fact that environmentally aware poets still do not receive much attention. ${ }^{3}$ The focus on rereading many poems written during Romantic Movementsuch as poems of Wordsworth or Whitman causes the unpopularity of

${ }^{1}$ Glotfelty, Cheryll and Fromm, Harold. The Ecocriticism Reader, Landmarks in Literary Ecology. (Athens, University of Georgia Press, 1996) p, xviii-xviv

${ }^{2}$ Sumathy, U. "The Nature-Culture Interface in Andal'sThiruppavai." Indian Literature. 51.6 (2007) p, 188.

${ }^{3}$ Bryson, J.Scott. The West Side of Any Mountain. (Iowa, University of Iowa Press, 2005) p, 1 contemporary nature poets. In Bryson's view, actually what contemporary nature poets writes nowadaysis different from traditional nature poets like Wordsworth or Whitman ${ }^{4}$, especially as modern day nature poetsalready have awareness toward environmental issue. Hence, he proposes that a terminology should be coined regarding this particular issue. Bryson asserts that "eco poetry" is an apt definition for contemporary poets writing about environmental issue. Eco poetry is contemporary poems written by environmentally aware poets.

The focus of this paper is the reading on selected poems by eco poetry poets. Both are contemporary poets writing about the situation in their homeland. Their focus is especially concerning relationship between human and non-humannature. Firstly, this paper focuses on the background of two poets especially as both poets still do not receive much attention. Ayurzana is native Mongolian, graduated from Maxim Gorky Literary Institute in Russia. ${ }^{5} \mathrm{He}$ is quite

\footnotetext{
${ }^{4}$ Bryson, J.Scott. "Finding the Way Back: Place and Space in the Ecological Poetry of Joy Harjo." MELUS. 27.3 (2002) p, 169

5 "Biography." www.ayurzana.mn Web. 21 October 2015. <http://www.ayurzana.mn/page/45/>
} 
prolific writer, not just write poetry but he also delves in prose. His first novel, The Illusion (2003) received the AltanOed literary prize from the Mongolian government and later published as a trilogy with The Debt of Ten Dreams (2005) and Born of Echo (2007). His most well-known work is his novel The Legend of the Shaman (2010) which is rewarded as the best Mongol literary work in 20002010 by Goo Maral Academy of Mongolia. While he is more acclaimed for his novel achievement, he is also an accomplished poet with all of his selected poems were published under the title "Meditations" in 2013. His poetry mainly talks about the close connection Mongolian people have toward nature and loaded with awe and reverence toward nature.

Second poet this paper focuses upon is Yong ShuHoong. Yong ShuHoong was born in 1966 in Singapore. Yong ShuHoong is the author of five poetry collections, including Frottage (2005) and The Viewing Party (2013), which won the Singapore Literature Prize in 2006 and 2014 respectively. ${ }^{6}$ His poems and short stories have been published in literary journals and anthologies, including Quarterly Literary Review Singapore, Language for a New Century (W.W. Norton, 2008) and BalikKampung (Math Paper Press, 2012). An interesting fact about Hoong is that he actually majoring in computer science and he honed his skill in writing poetry by reading the works of authors from Beat Generation. ${ }^{7}$ As the Beat Generation influences him, many of his poetry portray life of a young man and his perception toward the modern world. His poetry commonly takes place in modern cities like Adelaide, Chicago, and Singapore. Hence, in this paper's perspective he will make a nice contrast to Ayurzana's poetry especially on regard how both poets portray their surrounding in line with ecological focus of eco poetry.

\footnotetext{
${ }^{6}$ www.singaporewritersfestival.com .Web. 21 October 2015. $<$ https://www.singaporewritersfestival.com/nacswf/ nacswf/author-speaker/Yong-Shu-Hoong.html>

7"Singapore Infopedia". Web, 21 October 2015. $<$ http://eresources.nlb.gov.sg/infopedia/articles/SIP _1640_2010-01-31.html>
}

In analyzing the environmental issue this paper usesYi-Fu Tuan's concept of place and space thatJ.Scott Bryson in his The West Side of Any Mountain (2005) elaborates more. Bryson believes that there are two major concerns of ecopoets.

(1) to create place, making a conscious and concerted effort to know the more-than-human world around us; and (2) to value space, recognizing the extent to which that very world is ultimately unknowable $^{8}$

Tuan defines placeas, "enclosed and humanized space." In his example, a neighborhood begins as an abstract concept for the new resident. It is only after s/he interacts and becomes accustomed with its citizens than the abstract construct begins to be identified, recognized, and eventually become home for the new resident.This is what placemeans, or in Tuan's term "enclosed and humanized space."Place should make its inhabitantsexperience what Tuan coined as "topo philia", the affective bond between people and place or setting. ${ }^{10} \mathrm{In}$ relation with ecopoetry, Bryson asserts that ecopoets are place maker; they are narrating the story about their surroundings, their place, with hope that their reader will also discover and nurture the sametopophiliac devotion to their own place. $^{11}$ Hence, their poems become model on how their readers should also experienceclose connection and awareness to the nature in their own surrounding.

While place is a definable concept, spaceis more abstract. Place can be interpreted as "domesticated space", there is only a small section that can be domesticated and grasped while space is always infinite, ungraspable. This paper analogies it with steppe, which in this

\footnotetext{
${ }^{8}$ Bryson, J.Scott. The West Side of Any Mountainp, 8

${ }^{9}$ Tuan, Yi-Fi. The West Side of Any Mountain p, 9

${ }^{10}$ Tuan, Yi-fu and and Gretchen Holstein Schoff. Two Essays on a Sense of Place. (Madison:

Wisconsin Humanities Committee, 1988) p, 4

${ }^{11}$ Bryson, J.Scott. The West Side of Any Mountain p, 11
} 
paper's view is quite apt in describing this phenomenon. Steppe is vast untamed land, and even though there is civilization there, it will only cover a small portion of steppe. Hence, the domesticated space or the place is actually only a small portion of the larger space. In relation with eco poetry, an eco-poet will only be able to perceive his/her own place, as there are limitations in human senses. Hence, the more we learn about the natural world, the more we realize that there is how much we do not, and perhaps we will never know. $^{12}$ This is what Relph coined as "environmental humility ${ }^{13}$ ", realization that nature is the master of this world instead of humankind. Bryson asserts that ecopoet should recognize the dichotomy of place of space, the attention to the finitude of place synchronized with the boundlessness of space. ${ }^{14}$ In other world, an ecopoetneed to have "topophiliac devotion" toward their own place in order to have an emotional sense of belonging so that readers can experience the same feeling in his/her own society. Yet ecopoetsmust also realize that what $\mathrm{s} / \mathrm{he}$ expressed in their poetry is only a small representation of the infinite space.

These conceptsare used to analyzehow both Ayurzana and Hoong depict the environment in their eco poetry. First, this paper examines how both poets function as "place-maker", narrating the situation in their surrounding so that their reader can also begin to have similar nature awareness with howboth poets deliver their poetry. Ayurzanashows his awareness of his place, especially concerning his Mongolian identity, homeland, and background. In I Worship Sunrise, several terminologies illustrate his Mongolian identity. One example is in this stanza:

How old is the mosquito

Squashed between the pages

\footnotetext{
${ }^{12}$ Bryson, J.Scott. The West Side of Any Mountain

$\mathrm{p}, 18$
${ }^{13}$ Relph, Edward. Rational Landscapes and Humanistic Geography. (Totowa, NJ:

Barnes and Noble, 1981) p, 168.

${ }^{14}$ Bryson, J.Scott. The West Side of Any Mountain. P 18-19
}

\section{Of the ancient sacred sutra ${ }^{15}$}

This paper places emphasis especially on the phrase "ancient sacred sutra." This shows how Ayurzana in his poetry highlight his identity as Mongolian. This is especially interesting, especially when we see that Buddhism actually is not native Mongolian religion. Wallace acknowledges that in the thirteenth and in the late sixteenth centuries, Mongolians adapted Buddhist deities, symbols, and practices to their nomadic and pastoral lifestyle, pre-Buddhist beliefs and customs, and artistic and intellectual pursuits. $^{16}$ The dichotomy between Buddhist and traditional shamanistic tradition in Mongolian culture can actually be found also in Ayurzana's other works. Previously this paper mentions that the most well-knownAyurzana's literary work is a novel entitled The Legend of the Shaman which deals with the Shamanistic culture in Mongol society. Therefore, in Ayurzana's fictions he depicts the diverse influences of both native and foreign heritage of the Mongolian people.

Besides showing the heritage of his Mongolian ancestry, Ayurzana's poems also portray the close connection Mongolian people have toward nature. One illustration is in his poem Flowers of Death that highlights the unique ecosystem in the steppe. Ayurzana describes how certain flowers can only be found in Mongolian steppe.

This smell has no equal.

One cannot label a smell like this good or bad.

From this stanza, Ayurzana emphasizes the uniqueness of certain Mongolian flower. He describes it hyperbolically,

\footnotetext{
${ }^{15}$ Ayurzana, Gun G. I Worship Sunrise: Four Poems, Trans. Christopher Merrill. Web, 20 October 2015.

http://blog.bestamericanpoetry.com/the best ameri can_poetry/2008/10/i-worship-sunri.html>

16 Wallace, Vesna A. Buddhism in Mongolian History, Culture, and Society (New York : Oxford University Press, 2015)p. xv

${ }^{17}$ Ayurzana, Gun G. Flowers of Death, Trans, Lisa Fink. Web, 20 October, 2015 < http://www.ayurzana.mn/newsView/170>
} 
proclaiming how it "has no equal" and "doesn't exist anywhere else". In this paper's perspective, this shows how preservation of certain endangered plant species is a major concern in Mongolian society. This can be shown especially how the tone of this poem is still cheerful, because he is still able to experience it firsthand. His tone will be more mournful and full of lamentation if the specific flower he describesno longer exists.

The title of his poem also highlights the danger of the extinction of certain species. He labels the flowers as "flowers of death"; this is quite ironic especially when we see how the poem does not deal with "dangerous" or "poisonous" flowers that can cause death. Yet his title can be interpreted as warning so that this flower should always be preserved, or else the flower will die and future generation cannot see it anymore. Regarding this phenomenon, this paper illustrates how a Native American poetNilanorthsunlamentsthe loss of traditional culture and tradition.

$$
\begin{aligned}
& \text { i can't speak of } \\
& \text { many moons } \\
& \text { moving camp on travois } \\
& \text { i can't tell of } \\
& \text { the last great battle } \\
& \text { counting coup or } \\
& \text { taking scalps } \\
& \text { i don't know what it } \\
& \text { was to hunt buffalo } \\
& \text { or do the ghost dance }{ }^{18}
\end{aligned}
$$

This poem illustrates the loss of reference, how a person is dispossessed of his/her traditional heritage because it does not survive into the present era. North sun no longer knows to "hunt buffalo" or "do the ghost dance" as she only learns it from books instead of experience it herself. On the contrary,Mongolian people still preserve their heritage and their natural environment as depicted in Ayurzana'sFlowers of Death and I

\footnotetext{
${ }^{18}$ Nila, Northsun. Moving Camp too Far. Qtdin Bryson, J.Scott. The West Side of Any Mountain. p, 14
}

Worship Sunrise. How Ayurzanais still able to celebrate the beauty of unique Mongolian flowers that he sees it himself illustrate the conservation of nature in Mongolian society.

Compared with Ayurzana that emphasizes his Mongolian ancestry and heritage through his poetry, Hoong's poetry does not particularly focus on single cultural or ethnical aspect. This paper believes that regarding place, Hoong is more as an urban poet, dealing with the concern of modern people in general instead of on his own Chinese and Singaporean background.Influenced by Beat Generation, he particularly gives emphasis on how individual is alienated by what he considered as decadent and hedonistic lifestyle. His style of Poetry also reflects his Beat Generation's influences. While Ayurzana'spoems have many traditional poetry characteristics like how it is divided in stanzas, Hoong uses paragraphs instead.Hence,Hoong's poetry can be classified as narrative poetry, poetry thatnarrates a story.

Another difference between two poems can also be found in their theme and setting, Ayurzanahighlights life in Mongolian society, which is still predominantly rural and agrarian. On the contrary, Hoong depicts life of urban dwellers. One example is in his poem entitled Adelaide. This poem presents the life of a young Chinese who moved away to Adelaide. What is interesting is how Hoong places contrast between living in rural and urbanarea in this quotation

I still remember clowning with my cousins in their big houses when we were much younger...And they grow fruits that we can only buy in supermarket here ${ }^{19}$

While in urban cities land islimited and expensive, on the contrary there is still many empty spaces in rural area. Trees, plants, and other floras can thrive in this particular environment. On the contrary, the anthropocentric view of urban dweller

\footnotetext{
${ }^{19}$ Hoong, Yong Shu. Adelaide. "Quarterly Literary Review Singapore." Web, 21 October 2015. < http://www.qlrs.com/poem.asp?id=373>
} 
which places human above everything makes many trees and plants are cut down for the sake of urban development. Hence Hoong criticizes the fact that in rural area we can "grow fruits" while in urban area we must "buy fruits."

Hoongdelivers another critique toward the disconnection between human and nature especially among urban dwellers in his The Complaints Choir. This poem satirizes how urban people rarely now hear cicadas chipping. Hence, if people hear it for the first time they would be alarmed, and having no reference of what cicadas should sound like they will guess that it is ,"sci-fi sound effects- part syntactic noise, part deafening silence. ${ }^{20}$ " This poem illustrate also the danger of the disconnection between human and nature, as people are losing their connection, their ability to read the sign of the earth. They are now more absorbed in their gadgets and computers and do not give particular attention about how earth and nature actually have their own voice as symbolized in the singing of the cicadas. To compare, Ayurzana'sEastern Poem shows how in rural area we can, "hear a branch breaking somewhere" 21 , which indicates that Mongolian people can still hear the voice of the nature. On the contrary, modern urban people are detached from their landscape.

After analyzes the issue of place, now this paper moves on analyses the issue of space. This is especially regarding how there is an awareness of the infinitude of nature, about how human could not possibly decipher the exact scope or it. Ayurzana has more awareness about this particular issue, as we noted that Mongolian people still have close connection toward nature and Mother Earth. In Eastern Poem, Ayurzanashows his environmental humility, recognizing the fact that nature,

\footnotetext{
${ }^{20}$ Hoong, Yong Shu. The Complaints Choir. Web, $20 \quad$ October 2015

http://www.yongshuhoong.com/>

${ }^{21}$ Ayurzana, Gun G. Eastern Poem. Trans. Christopher Merrill. Web, 20 October 2015. < http://blog.bestamericanpoetry.com/the_best_ameri can_poetry/2008/10/i-worship-sunri.html $>$
}

not human that is actually the master.Ayurzana portrays it as:

Suchhappiness

Tosee the sunrise on the steppe!

When I feel its calm light

I forget my sorrow.

To breathe such air,

be human is enough!

Oh...

After that, let God take his brush ${ }^{22}$

Ayurzana shows what Bryson coined as space-conscious ${ }^{23}$, how he is aware that nature is actually infinite and untamed, human can only tame a small portion of it. Hence,Ayurzana shows a deep humility with regard of the relationship between human and nonhuman nature.It is not human who control the environment, but nature itself and God. This is shown in how he proclaimsthat, "to breathe such air, be human is enough." $\mathrm{He}$ is grateful that the symbiosis between Mongolian people and nature is still quite strong, how nature gives fresh air to improve the life quality of people there. Nature can survive without people, yet on the contrary, people cannot survive without nature. Similar view is found also in his other poem I Worship Sunrise. Ayurzana describes how he, "worship Sunrise, oh my morning, and worship Moonrise, oh evening twilight. ${ }^{24 "}$ This illustrates also how people should be aware that every day in their life, how sun give light in the morning and moon illuminate the darkness during night makes them indebted toward nature. By showing his grateful reception toward nature, Ayurzana hopes the reader of his poem can also become aware and adopt similar view with what he illustrates in his poetry.

\footnotetext{
${ }^{22}$ Ayurzana, Gun G. I Worship Sunrise: Four Poems

${ }^{23}$ Bryson, J.Scott. The West Side of Any Mountain. P, 21

${ }^{24}$ Ayurzana, Gun G. I Worship Sunrise: Four Poems
} 
Differently with Ayurzana, Hoong does not show his awareness toward the concept of space, about how human actually lives in a place that they do not own. He gives more focus on the issue of place making. Hoong narrates the story of urban dweller and they are losing their awareness toward nature. People can only see the fruits in supermarket instead of seeing in on the treesand their unawareness concerning the voice of the cicadas. Hence Hoong' poemsfocus more on this disconnection between human and nature. This affirmswith what Relph states that,"place molds us as well as vice versa. ${ }^{25}$ Ayurzana'sspace-

consciousnessis caused by the fact that his society still reveres and preserve nature. On the other hand, urban society does not have the same worldview; therefore, the focus on Hoong's poems is to criticize this disconnection. While Ayurzana's poetry praises the proper relationship between human and nature among Mongolian rural society, Hoongtries to correct the imbalance addressed in the life of modern urban people.

\section{CONCLUSION}

This paper concludes that the both poems focus on different ecological issue. Coming from a society with close connection between human and nature, Ayurzana's poetry focuses on presenting and preserving this harmony. While on the contrary, Hoong criticizes the unawareness of modern urban society regarding human nature relationship. The voice of the earth is often disregarded due to the anthropocentricview that places human as the master. This view is actually not correct, nature can sustain itself without human guidance, yet on the contrary, human being cannot function without the help of nature. Hence similar with whatAyurzana portrays in his poems, we should have space-consciousness, aware that nature is ownerless, human is not in control of nature, but it is other way around.

\footnotetext{
${ }^{25}$ Relph, Edward. Rational Landscapes and Humanistic Geography. P, 169.
} 


\section{REFERENCES}

"Singapore Infopedia". Web, 21 October 2015.

<http://eresources.nlb.gov.sg/infopedia/articles/SIP_1640_2010-01-31.html>

Ayurzana, Gun G. Eastern Poem. Trans. Christopher Merrill. Web, 20 October 2015. < http://blog.bestamericanpoetry.com/the_best_american_poetry/2008/10/i-worshipsunri.html>

---. Flowers of Death, Trans, Lisa Fink. Web, 20 October 2015 < http://www.ayurzana.mn/newsView/170>

---,. I Worship Sunrise: Four Poems, Trans. Christopher Merrill. Web, 20 October 2015. $<$ http://blog.bestamericanpoetry.com/the best american poetry/2008/10/i-worshipsunri.html>

"Biography." www.ayurzana.mn Web. 21 October 2015. http://www.ayurzana.mn/page/45/

Bryson, J.Scott. "Finding the Way Back: Place and Space in the Ecological Poetry of Joy Harjo." MELUS. 27.3 (2002) p, 169

---. The West Side of Any Mountain. (lowa, University of lowa Press, 2005) p, 169-196.

Glotfelty, Cheryll and Fromm, Harold. The Ecocriticism Reader, Landmarks in Literary Ecology. (Athens, University of Georgia Press, 1996) p, xviii-xviv

Hoong, Yong Shu. Adelaide. "Quarterly Literary Review Singapore." Web, 21 October 2015. $<$ http://www.qlrs.com/poem.asp?id=373>

---. The Complaints Choir. Web, 20 October 2015. < http://www.yongshuhoong.com/>

Nila, Northsun. Moving Camp too Far. Qtdin Bryson, J.Scott. The West Side of Any Mountain.

Relph, Edward. Rational Landscapes and Humanistic Geography. (Totowa, NJ: Barnes and Noble, 1981)

Sumathy, U. "The Nature-Culture Interface in Andal's Thiruppavai." Indian Literature. 51.6 (2007) p, 187-190.

Tuan, Yi-fu and Gretchen Holstein Schoff. Two Essays on a Sense of Place. (Madison: Wisconsin Humanities Committee, 1988)

Wallace, Vesna A. Buddhism in Mongolian History, Culture, and Society (New York: Oxford University Press, 2015)

www.singaporewritersfestival.com. Web. 